\title{
GAMIFICATION TO IMPROVE STUDENTS' ENGAGEMENT IN LEARNING ENGLISH
}

\author{
Hadirotun Nikmah, English Education Study Program, Faculty of Teacher Training and \\ Education, Universitas Islam Malang \\ hadirotunnikmah8@gmail.com
}

\begin{abstract}
This paper aim to review some theories and previous studies on the application of game-based learning platform to improve students' engagement in learning English. Learning English is crucial and is not negotiable in an Industry 4.0 era to communicate and to collaborate globally. In fact, not a few students find it difficult and lack of enthusiasm in learning English. One of the major problems is the teaching method which is less interesting and tends to be boring. Therefore, one of the solutions to resolve this problem is through the implementation of gamification. One of the most well-known employed gamification tools is Kahoot. Kahoot is one of the most used application to impove students' engagement in learning English. Kahoot is a free game-based learning platform that can be used by teachers and students. Hence, this paper will describe at first the challenges in teaching English language in digital era. Further, it discusses the theory of gamification in education, advantages of gamification, the description of Kahoot, advantages of using Kahoot and how to apply Kahoot in English classroom. Some previous research highlighting the effect of using Kahoot on the students' engagement in learning English is the main point covered next. The last part of this paper will present conclusion and pedagogical implication as a closing note. The findings suggest that KAHOOT is proven to be useful in initiating and fostering students' engagement in language learning and increasing their language skills. The study hopes to provide insights for better implementation of game-based technologies.
\end{abstract}

\section{Keywords : gamification, Kahoot, students' engagement}

\section{INTRODUCTION}

Information Communication and Technology (ICT) in the Industrial Era 4.0 has become a fundamental necessity in supporting the effectiveness and quality of the education process. It is in line with Ares et al. (2018) who state that some researchers have identified an increase students' motivation when implementing ICT in their teaching and learning process. One of the utilization of ICT that is widely used in learning media is gamification. It is in line with Tara and Samer (2018), who states that teachers are looking for opportunities to implement a gamified method in a class that aims to involve learners in the learning process.Gamification is a game 
based-learning that is different from serious games. It is like what Woodcock and Johnson (2017) who says that "Gamification is understood as the application of game systems competition, rewards, quantifying player/user behaviour - into non-game domains, such as work, productivity and fitness."

In an educational environment, gamification has an important role especially to attract students' attention. It is like with Solanki and Phil (2012) who point out that the choices presented by the technology vary considerably as well as making teaching more attractive and more productive in terms of refinement. In this case, gamification is needed to overcome students' saturation due to less precise methods. With gamification, a very boring classroom atmosphere becomes more enjoyable and comfortable. This statment is supported by Tara and Samer (2018, p. 37) who states that "gamification motivates students through a magic formula of fun and meaningful learning that can be attributed to the design elements of the game varying from points and levels for rewarding and ranking to incentives and badges to challenge and excite." From the explanation above, it can be concluded that gamification can be a promisingmethod in the digital era to attract students in the English learning process.Students will be easier to learn and capture what teachers convey with new and fun media. This proves that the game-base technology is like Kahoot! Must be carried out in class from time to time to involve students in class participation.

\section{ENGLISH TEACHINGANDLEARNINGIN THEDIGITAL ERA}

The 4.0 industrial revolution era has an impact on education. One of the emerging new paradigms is the digital platforms in the educational environment. Student is required to learn and utilize technology especially in the education environment. In additionSolanki and Phill (2012) says that technology is utilized for the upliftment of modern style, it satisfies both visual and auditory senses of the students. With the technology can sharpen students' senses so that they can be more sensitive and quickly capture the material well. This requires teachers to adapt technological developments in implementing teaching methods. According to Candradewi (2017), in this digital era, technology has an important role in leading the learning process and helping students to become autonomous learners.It can be conclude that the teacher is required to adapt with current trends. One of them is by integrating Internet network through application in mobile phone. According to Hariharasudan and Sebastian (2017, p. 2), "applications of the Internet of Things (IoT) and digitalization of the teaching and learning process and industrial operations done through the medium of English are known as Digital English, simply saying, the 
electronic version of English is called as Digital English, which is widely witnessed in the multifarious functions of fourth industrial revolution." There are many great applications that bring the positive impact in teaching English. Teaching English with fun platform brings ease in all aspects of life. According to Hariharasudan and Sebastian (2017), social life has become easier than ever with technological innovations and advances from technology in this digital era. It can be concluded that teacher must create new method in the classroom so that the students will be passionate and enjoy in learning process.

\section{GAMIFICATION IN EDUCATION ENVIRONMENT}

Gamification is a new term that is being discussed. In the last decade the term of gamification emerged around 2010 where technological developments at the time were very rapid. Gamifiction is non-game based learning which has become an increasingly popular approach in increasing users' enthusiasm in a variety of contexts, including in the world of education. According to Jihan et.al (2018), gamification has been widely applied to areas such as education, fitness and health, but it is still a new thing in the world of education. Gamification is a free platform that focuses on non-game-based learning which invites users to be more involved in solving a problem. The concept that is presented on this platform is very different from the other game. This game uses level system, scoring and a wide range of tools that focuses as medium of learning. Gamification gets a good welcome in the community especially in education environment. There are three categories in the gamification namely, the internal gamification, the external gamification, and the behavior-change gamification. First, the internal gamification is a gamification to increase productivity which creates new innovations in business or organization. Second, external gamification is a game that involves parties outside the company or organization. External Gamification aims to improve the relationship between business and customer and increase profits in a company or organization. Third, the behaviourchange gamification is to form a new habit against a person. One example is to redesign the class, so students are comfortable and passionate about learning. Such gamification programs are usually supported by the government. Lastly, gamification can be the right choice method as a learning medium since this method can draw students ' interest and enjoyment in learning.

\section{ADVANTAGES OF GAMIFICATION IN TEACHING AND LEARNING}

In this section the author will discuss what the benefits of the gamification are. Gamification learning method has several advantages than the other learning methods. In this case gamification offers a new learning experience. This platform offers a various gaming types 
that contain learning. Related to the István et.al (2017) reveals that the application of gamification is able to overcome the saturation of students during the learning process and make the learning process more interesting.

Mostly all game has the same characteristics. Each game has a grace period of the game and some other rules set. The characteristics that made the challenged students became winners in each of the game. Not only that, gamification presents an atmosphere in the classroom so emotionally and enthusiastically. According to Joey and Jessica (2011), gamification provides an experience to explore and experiment more with rules, emotions and social roles.Emotions factor becomes the motivation of children in the learning process takes place. In this case, students compete to get a good score and also feel challenged by the game. Students work hard to get satisfactory results. The next positive impact of gamification is motivation. Motivation is one of the main factors in teaching gamified, which is an important aspect in students' engagement classroom. Along the same linewith Maja (2017), who points out that more motivated, good involvement, and the emergence of a sense of want to win and actively learn is the effect of the use of non-games. The next impact of using gamification is to make students more focused in understanding the material. This is because the learning methods used are very indifferent and do not make the students feel burdened. So, students become more enjoy and easily capture the material. The next positive impact from gamification is to encourage students to be more active in completing their assignments. Gamification method makes the classroom more alive. From some of the positive impacts above, it can be concluded that the gamification is how to make the learning activities more fun and comfortable so that the gamification is suitable to apply in education environment.

\section{WHAT IS KAHOOT?}

As explain in the previous discussion, there are many types of gamification for the learning process and one of the gamification types is Kahoot. Kahoot is a free non-game based learning platform. Kahoot! was founded in 2012 by Morten Versvik, Johan Brand and Jamie Brooker who in a joint project with the Norwegian University of Technology and Science, teamed up with Professor Alf Inge Wang, and were later joined by Norwegian entrepreneur Åsmund Furuseth (Kahoot! Investor Update, 2018). The technology is based on research conducted by Kahoot! Co-founder of Morten Versvikfor his master's degree at NTNU, who was a student of Professor Wang's at the time (Kahoot! Investor Update, 2018). In 2013 Kahoot was officially launched. More than 20 million users have downloaded or using the platform. In 2017 
Kahoot was downloaded more than 70 million user. It is very fantastic digit especially kahoot is a very new application and can attract people to try it. Kahoot's users have made this application into top 3 tool as an educational application in the US. In 2018 Kahoot launched its latest version, Kahoot! Plus and Pro in Q1 with major update in Q2 (Kahoot! Investor Update, 2018). In the latest version kahoot also got a positive respond by the community. Kahoot offers a variety of interesting quizzes to apply in the classroom. The learning that had been very boring and saturating it became very enjoyable with the kahoot. Kahoot make the students more understand about the context of the study that is difficult to understand. If students want to run this game, they must have an internet connection. All the quizzes in Kahoot only can be accessed online.

Kahoot is a game that can be played in two ways, individually and groups. There are a variety of quizzes ranging from English, science, mathematics and many others. The quiz found in Kahoot is largely multiple choices with varying tiers. The quiz is very interesting and very challenging, because each of the quizzes has several levels ranging from easy to difficult. Students can easily access the quiz via a smartphone, laptop or tablet. Another unique thing in Kahoot is the multiple choices with a variety of shapes and colors. The multiple choice forms in kahoot are triangular, round, square, trapezoid, etc. Striking color selection also attracts students to play Kahoot. Although Kahoot is a learning media-based game where it usually looks very serious but the designer adds sound effects to a game that makes students more enjoy when playing. The success of this platform can be seen through the students who enjoy the existing games and do not realize that they are in learning process. Up until now Kahoot became one of the dominating applications in the educational environment.

\section{ADVANTAGES OF KAHOOT}

Downloaded more than 70 million users, of course this application has enormous privileges and benefits. The advantage of Kahoot is that teachers can make quizzes or take advantage of quizzes that are already on the platform. Teachers can insert videos, pictures or text. Besides, the teacher can also set the time duration for the quiz that has been made. Another benefits contained in Kahoot is teachers can also conduct surveys or create polls on the application. Teachers can see how deep the students' understanding in material that has been taught. Teachers can also easily monitor the activity of learners. It can be seen through the application of any number of students who can answer correctly, how many people who answer wrong and how many people who do not answer. All these activities are well monitored. 
From the students' side the benefit that can be felt when using Kahoot among others; students become more motivated in learning, more involved in the learning process, have different learning experiences and are more enjoyable and not boring. The first positive impact when using of Kahoot is students more motivating in learning. The quizzes in Kahoot are attractive and have varying degrees of difficulty. It is certainly challenging the students to be more passionate in getting scores in each quiz. Based on the study done, by Adlina et al. (2018) say that Kahoot! not only promotes an interactive fun learning environment but also challenges students in the learning process. The second is that students are more involved during the learning process. With Kahoot student involvement is much greater than before. An interesting learning method that makes students feel comfortable will make students participate during the learning process. The third student can have learning experience. With the new methods used to make students have a new and different learning experience from the previous method. It is in line with Ramón and José (2016, p. 2) who states that "game-based learning refers to the use of games to enhance the learning experience, while maintaining a balance between content and gaming and its application in the real world." Not only that, Kahoot also makes a positive impression on users so that it can increase the insight when using this platform. The last, Kahoot makes the classroom more enjoyable and not boring. According to Halise (2018), a positive response about Kahoot is shown in a study stating that students feel Kahoot is a fun, informative, perfect application. Kahoot make students more enjoy with interesting features and challenging quizzes that do not pose boredom or saturation. It can be conclude that this application has many benefits. Kahoot can make the classroom more alive, comfortable and enjoyable. This application has made it successful for students to feel like they are not studying in class.

\section{HOW TO APPLY KAHOOT?}

As previously explained, to be able to access Kahoot is very easy. Students or teachers can access this application via smartphones, laptops, or tablets. If students access from smartphone, they can download it in Playstore or Apple Store that available on their smartphone. Students can also use the laptop and can access it through https://create.kahoot.it/. If students or teacher still don't have an account, please register first. Students or teachers can use their email account to register. Kahoot offers a variety of quizzes such as English, mathematics, science and so on which each quiz has some levels. Kahoot has 4 features such as games, quizzes, discussions and surveys. The unique of this platform which is different with another quiz 
platform is the answers in the quiz will be represented by images and colors. Participants are asked to choose an image or colour that is appropriate with the answer.

For the quiz creation, teachers can add questions, an alternative answer, determine the correct answer, set the time duration for the quiz and other settings as needed. Every quiz is automatically saved to their Kahoot account, so it is easy to see the pre-built quiz. Once the quiz is done, teacher can play the quiz in the learning process. The quiz that has been created will be identified by a PIN. Before the quiz begins, teacher must publish the PIN first. After that, the student enters with PIN and can access the quiz. During the quiz running, teachers take full control of the quiz. Teacher can set when the question must be showed in the displayed.

When the game is over, Kahoot shows the results of the quiz and the student acquisition score. The next step, teacher can see the results of multiple choice analyses. The teacher can press the 'save result option', then select Direct Download and clicks 'save to my computer.' The files that are downloaded in Excel are the items. Teachers can see the correct percentage of students in answering questions. All the student mistakes in answering a quiz will look in detail. Teachers can also see the extent to which students are capturing a material that has been taught. Of course this is very beneficial to the teacher and to do the evaluation material in a teaching. Teachers will be easier to teach after knowing any material that students find difficult and still cannot be arrested by the students well.

\section{RESEARCH ON EFFECTS OF USING KAHOOT}

There are many definitions arose from numerous studies regarding the term of student engagement. The author took from two researchers article as the previous study.

The first study is carried out by Hazwani et.al which is aimed to investigate the use of Kahoot! for classroom engagement. The tittle of the research is 'Using Game-based Technology, Kahoot! for Classroom Engagement" was conducted in 2018. Two researchers were involved in this small case study where one was a non-participant observer and the other was the interviewer, who also acts as the teacher monitoring the game. A set of 29 Faculty of Biomedical Engineering (FBME) students comprising of 6 males and 23 females from one of the first year English classes were chosen. The instrument used in this study was Kahoot and recorded interview sesion. Firstly, for the Kahoot! quiz result, the scoresheet was obtained on the platform itself to see the overall performance of each group with regards to their synonym skill. Secondly, the recorded interview session was transcribed and all significant responses were listed down according to the three questions asked during the interview session. Finally, from the data already collected 
researchers can see and calculate that the students' engagement in the classroom by using Kahoot is very significant.

The second study comes from Halise which is aimed to investigate the implementation of using Kahoot in elementary school. The tittle of the research is 'Implementation of the Digital Assessment Tool 'Kahoot!' in Elementary School” was conducted in 2018. 23 students studying at the 4th grade and 1 teacher in Toki Şehit Jandarma Yarbay Alim Y1lmaz Primary School in Muğla province in Turkey participated in this study in the 2017-2018 academic years. The researcher used intruments by using questionnaires asking personal information questions and open-ended and closed-ended questions. The descriptive analysis technique was used for the analysis of the data. The item "The Kahoot! was interesting." was responded by the $4.3 \%$ of the students as "no", by the $8.7 \%$ of the students as "sometimes", and by the $87.0 \%$ of the students as "yes". As a result, it was concluded that the students were mostly satisfied with the Kahoot! application.

Based on the study done above, it can be conclude that Kahoot application give the significant impact for students' engagement and make students more enjoy and satisfied with their result. The implementation of Kahoot mostly makes students more motivation in learning process.

\section{CONCLUSION AND RECOMMENDATION}

Games are known to develop in terms of engagement.As a new learning method, gamification is better than the other learning methods. One of the types in gamification method is Kahoot application. In this Industrial Era 4.0, Kahoot become an alternative choice as a suitable learning medium applied especially in English classroom. Kahoot is one of the most practical and easy learning media. In the education environment, the use of Kahoot has been done, it aims to motivate learners to be interested in the material being taught. It is not separated from the importance of increasing the intrinsic motivation in learning process. As a great alternative to the learning process, the use of the Kahoot can improve students ' interest in learning process. Using Kahoot is not just making games, but rather efforts to create custom apps to apply the right concept of gamification. The main point is the right concept as well as a clear goal of building students' engagement in the learning process. The unique features and the interesting design make this application able to appeal to the user's enthusiasm to play it. Being one of the applications that bring a lot of changes to the learning process, this is demonstrated by the 
previous study that Kahoot has a positive impact. Implementation of the use of Kahoot brings the changing attitude of children who are more motivation and more satisfied with their results. The significant also seen from the student's engagement in the learning process when using Kahoot.The pedagodist innovations from using of Kahoot are teacher can create a comfortable and victorious learning and able to make an evaluation through Kahoot. Teachers must also properly use the Kahoot application so that students are not tired when the game progresses.

Teachers must choose the quizzes types with the right objectives so that they can make an evaluation of the teaching process.

\section{REFERENCES}

Al-Hadithy, T., \& Ali, S. (2018). Gamification in learning English for academic purposes: designing assessment for learning using Kahoot with uae undergraduate law students. IASTEM International Conference, 36-55.

Anggraeni, C. W. (2018). Promoting education 4.0 in English for survival class: what are the challenges? Journal of English Language, Literature, and Teaching, 2(1), 12-24.

Cahyani, F. (2018, February). The use of Think Pair Share technique to improve students' speaking performance. Research in English and Education (READ), 3, 76-90.

Cetin, H. S. (2018). Implementation of the digital assessment tool 'Kahoot!' in elementary school. International Technology and Education Journal, 2(1), 9-20.

Clara Sabandar, G. N. (2018). Kahoot!: bring the fun into the classroom. Indonesian Journal of Informatics Education, 2(2), 127-134.

Cózar-Gutiérrez, R., \& Sáez-López, J. M. (2016). Game-based learning and gamification in initial teacher training in the social sciences: an experiment with MinecraftEdu. International Journal of Educational Technology in Higher Education, 13(2), 1-11.

Hariharasudan, A., \& Kot, S. (2018). A Scoping Review on Digital English and Education 4.0 for Industry 4.0. MPDI, 1-13.

Lee, J. J., \& Hamme, J. (2011). Gamification in education: what, how, why bother? Academic Exchange Quarterly, 15(2), 1-5.

Leong, L. M., \& Ahmadi, S. (2017). An Analysis of Factors Influencing Learners' English Speaking Skill. Research in English Education, 34-41. doi:http://dx.doi.org/10.18869/acadpub.ijree.2.1.34

Licorish, S. A., George, J. L., Owen, H. E., \& Daniel, B. (2017). “Go Kahoot!” enriching classroom engagement, motivation and learning experience with games. International Conference on Computers in Education, 755-764. 
Malyakkal, P. E. (2014). Gamification in the classroom. International Journal of Innovative Research in Computer Science \& Technology (IJIRCST), 2(5), 52-55.

María, A. A., Jorge, B., Jesus, N. M., Javier, S. F., \& José, B. (2018). Results of the use of Kahoot! gamification tool in a course of chemistry. International Conference on Higher Education Advances (HEAd'18), 1215-1222.

Michos, M. V. (2017). Gamification in foreign language teaching do you kahoot? International Scientific Conference on Information Technology and Data Related Research, 511-516.

Mohd Muhridza, N. H., Mohd Rosli, N. A., Sirri, A., \& Samad, A. A. (2018). Using Game-based Technology, KAHOOT! for Classroom Engagement. LSP International Journal, 37-48.

Raba, A. A. (2017). The Influence of Think-Pair-Share (TPS) on Improving Students' Oral Communication Skills in EFL Classrooms. Creative Education, 12-23. doi:http://dx.doi.org/10.4236/ce.2017.81002

Rabah, J., Cassidy, R., \& Beauchemin, R. (2018). Gamification in education: Real benefits or edutainment? European Conference on eLearning, 1-6.

Retnowati, A. E., \& Ngadiso. (2018). Improving student's speaking skill using Think-Pair-Share method with Flashcard Media. Journal of Education and Practice, 9, 164-169. Retrieved from http://www.iiste.org/

Sampsel, A. (2013, April 29). Finding the effects of Think-Pair-Share on student confidence and participation. Honors College, 2-19. Retrieved from : https://scholarworks.bgsu.edu/honorsprojects

Sanjani, E. D. (2015). Improving students' speaking ability using Think Pair Share of cooperative learning for 8th grade students of MTs N Karangmojo. 2014-2015, pp. 1-201. Retrieved from https://eprints.uny.ac.id/23132/1/A\%20Thesis_Erlinna\%20Dewi\%20Sanjani_102022410 68.pdf

Shyamlee, S. D., \& Phill, M. (2012). Use o technology in English language teaching and learning; an analysis. International Conference on Language, Medias and Culture, 33, $150-156$.

Syafii, M. L. (2018). Using the Think Pair Share strategy to increase students' active involvement and to improve their speaking ability . IJEE (Indonesian Journal of English Education), 5, 62--80. doi:http://dx.doi.org/10.15408/ijee.v5i1.7679

Tint, S., \& Nyunt, E. E. (2015, February). Collaborative Learning with Think Pair Share. An International Journal (CAIJ), 2, 1-11. 
Tuan, N. H., \& Mai, T. N. (2015). Factors affecting students' speaking performance at Le Thanh Hien High School. Asian Journal of Educational Research, 3, 8-23. Retrieved from http://www.multidisciplinaryjournals.com/

Update, K. i. (2018, June). Retrieved May thursday, 2019, from https://kahoot.com/files/2018/06/Kahoot_InvestorUpdate_June2018_as_presented.pdf.

Usman, A. H. (2015). Using the Think-Pair-Share strategy to improve students' speaking ability at Stain Ternate. Journal of Education and Practice, 06, 37-45. Retrieved from http://www.iiste.org/

Varannai, I., Sasvari, P., \& Urbanovics, A. (2017). The use of gamification in higher education: an empirical study. (IJACSA) International Journal of Advanced Computer Science and Applications, 8(10), 1-6.

Wahidah, F. S. (2016). Students' speaking problems and factors causing it. Jurnal Logika, XVI, 1-11. Retrieved from http://www.e-journal.unswagati-crb.ac.id/

Woodcock, J., \& Johnson, M. R. (2018). Gamification: what it is, and how to fight it. LSE Research Online, 1-17.

Yanti, M., Rufinus, A., \& Regina. (2017). Improving students' speaking skills through ThinkPair-Share technique. pp. 1-9. 